\title{
Mucus Retention Cyst of Parotid Gland: A Rare Case Report
}

Dr. Mohammad Jaseem Hassan MD ${ }^{1 *}$, Dr. Shivani Panhotra $\mathrm{MD}^{2}$, Dr. Simpy Raj MD ${ }^{3}$, Dr. Sabina Khan $\mathrm{MD}^{4}$, Dr. Sujata Jetley $\mathrm{MD}^{5}$

\footnotetext{
${ }^{1,4}$ Associate Professor, ${ }^{2}$ Demonstrator, ${ }^{3}$ PG Student, ${ }^{5}$ Professor, Department of Pathology, Hamdard Institute of Medical Sciences and Research (HIMSR), Jamia Hamdard, New Delhi, 110062 India
}

DOI: $10.36347 /$ sjmcr.2020.v08i01.001

| Received: 26.12.2019 | Accepted: 03.01.2020 | Published: 10.01.2020

*Corresponding author: Dr. Mohammad Jaseem Hassan

\section{Abstract}

Swellings of the major salivary gland commonly lead to the differential diagnosis which includes benign and malignant tumors that are frequently associated with cystic degeneration or entirely cystic in nature. Mucus retention cysts are true cysts that rarely involve the major salivary glands. $6 \%$ to $9 \%$ of the major salivary gland swellings present as a cystic lesion and only 2-5\% of them are non-neoplastic in nature. A 21 year-old female patient presented with swelling in right parotid region for last one and half years. CECT of the parotid region show a well-defined oval fluid density lesion measuring $2.4 \mathrm{~cm} \times 1.9 \mathrm{~cm} \times 3.4 \mathrm{~cm}$ in the superficial lobe of the right parotid gland with extension into the deep lobe of the parotid gland. On FNAC, $7 \mathrm{ml}$ creamish fluid was aspirated which on microcopy showed foamy histiocytes in a mucoid background. A diagnosis of benign cystic lesion was made cytologically. The patient underwent right subtotal parotidectomy. Gross examination revealed a globular soft tissue piece with attached fatty tissue piece measuring $5 \times 4 \times 3 \mathrm{~cm}$. On cut section a cystic cavity identified measuring $3.5 \times 2.7 \times 2.0 \mathrm{~cm}$. Cyst cavity was filled with thick mucoid material. Microscopic examination revealed a cyst lined by cuboidal and partially by pseudostratified columnar epithelium. Interspersed mucus cells also present in lining epithelium. Lumen of cyst showed proteinaceous material. Compressed salivary gland parenchyma also seen at the periphery. No cellular atypia was seen. A diagnosis of Mucus retention cyst of right parotid gland was rendered histopathologically.

Keywords: Benign cyst, Mucus retention cyst, Parotid gland, Salivary duct cyst.

Copyright @ 2020: This is an open-access article distributed under the terms of the Creative Commons Attribution license which permits unrestricted use, distribution, and reproduction in any medium for non-commercial use (NonCommercial, or CC-BY-NC) provided the original author and source are credited.

\section{INTRODUCTION}

Mucus retention cysts are true cysts and are also referred to as salivary duct cysts, mucus duct cyst, sialocyst, and simple cyst that have a congenital or acquired origin. They commonly involve the minor salivary glands [1]. Most common sites are floor of the mouth, buccal mucosa, and lips. They rarely involve the major salivary glands. Only $6 \%$ to $9 \%$ of the major salivary gland swellings present as a cystic lesion and out of that only 2-5\% is non-neoplastic in nature [2].

The cysts in the parotid gland have an equal distribution among males and females, and usually presents as a unilateral painless swelling in parotid area without involving overlying skin and facial nerve. Most of the cases reported are of acquired origin attributed to an obstructive process. They show considerable variation in the type of epithelial lining [3].

Differential diagnoses of cystic swelling in major salivary gland include neoplastic and non neoplastic lesions. Neoplastic lesions include pleomorphic adenoma, warthin's tumor, mucoepidermoid carcinoma, low grade papillary cystadenocarcinoma, and metastatic squamous cell carcinoma and Non-neoplastic lesions are predominantly cysts that are lymphoepithelial cyst, salivary duct cyst, and dysgenetic cyst[2, 4].

Here we present one such case of mucous retention cyst affecting right parotid gland in 21-year old female.

\section{Case Report}

A 21- year-old female patient presented with swelling in right parotid region. She had noticed it one and half years back and since then swelling had progressively increased in size. The swelling was nontender, mobile, fluctuant, and soft in consistency. CECT of the parotid region show a well-defined oval fluid density lesion measuring $2.4 \mathrm{~cm} \times 1.9 \mathrm{~cm} \times 3.4 \mathrm{~cm}$ in the superficial lobe of the right parotid gland with extension into the deep lobe of the parotid gland. On Fine needle aspiration cytology (FNAC), 7ml creamish fluid was 
aspirated which on microcopy showed foamy histiocytes in a mucoid background. A diagnosis of benign cystic lesion was made cytologically.

The patient underwent right subtotal parotidectomy and the specimen was submitted for histopathological evaluation. Gross examination revealed a globular soft tissue piece with attached fatty tissue piece measuring $5 \times 4 \times 3 \mathrm{~cm}$. On cut section a cystic cavity identified measuring $3.5 \times 2.7 \times 2.0 \mathrm{~cm}$. Cyst cavity was filled with thick mucoid material. (Fig- 1) Microscopic examination revealed a cyst lined by cuboidal and partially by pseudostratified columnar epithelium and at places by squamous epithelium. Interspersed mucus cells also present in lining epithelium. The cyst wall is fibrocollagenous showing focal lymphoid aggregates, lymphocytes, histiocytes, plasma cells and few multinucleated giant cells. Lumen of cyst show proteinaceous material. Compressed salivary gland parenchyma also seen at the periphery. No cellular atypia was seen. Thus a diagnosis of Mucous retention cyst of right parotid gland was rendered histologically (Fig- 2,3\&4).

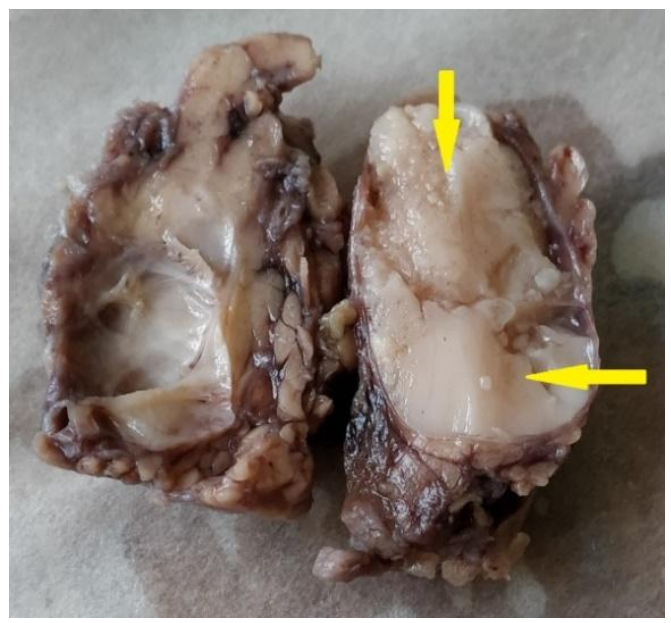

Fig-1: Gross photograph showing a cyst cavity filled with thick mucoid material (Yellow arrow)

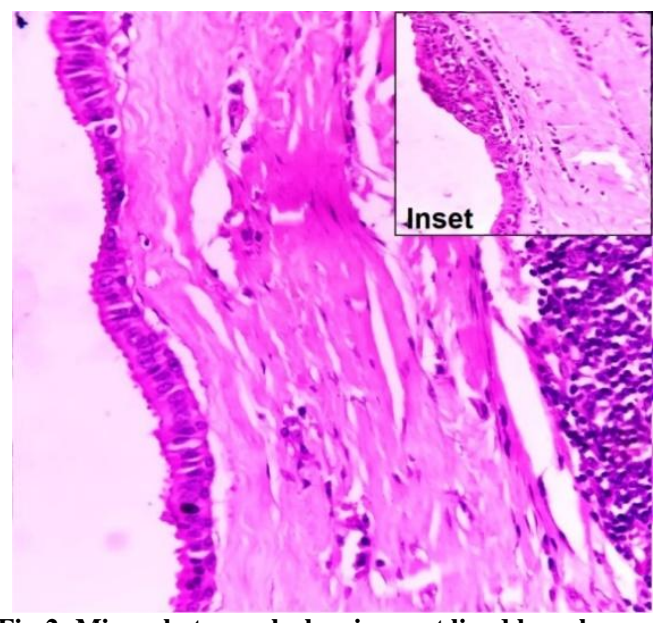

Fig-2: Microphotograph showing cyst lined by columnar epithelium and at places by squamous epithelium (inset) with cyst wall showing fibro-collagenous tissue. (H\&E X 400)

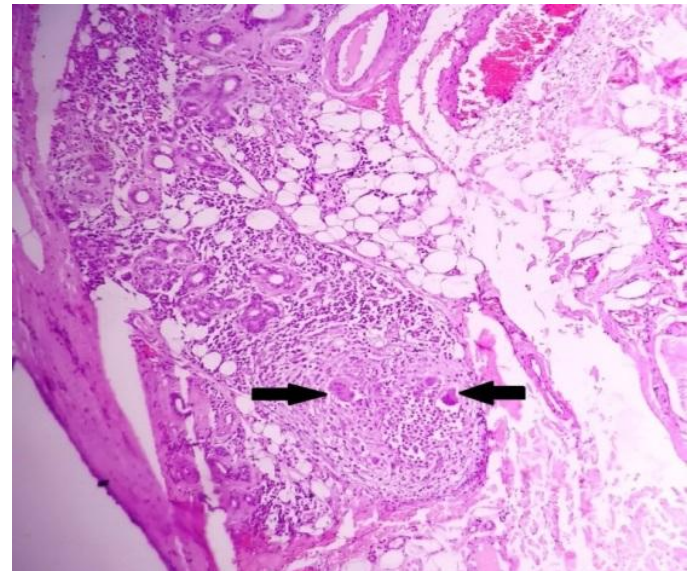

Fig-3: Microphotograph showing giant cell reaction. (H\&E X 100)

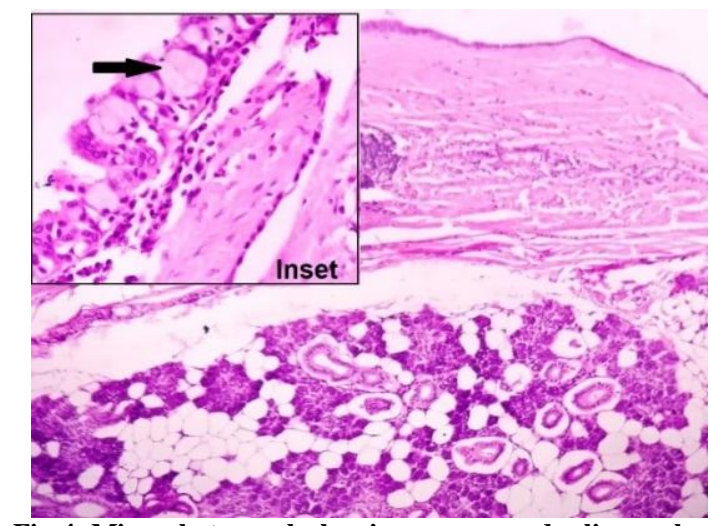

Fig-4: Microphotograph showing compressed salivary gland parenchyma (H\&E X 100) and inset showing mucus cells (Black arrow) in lining epithelium. (H\&E X 400)

\section{DISCUSSION}

Retention cyst most commonly involves the minor salivary glands and they rarely involve the major salivary glands. However when they occurs in major salivary glands, the parotid gland is affected more frequently by cysts and congenital lesions than any of the other major salivary glands. A cystic lesion can occur in any region of parotid gland and may be difficult to diagnose, particularly if it is located deep to facial nerve. They are usually unilateral, simulating a parotid tumor [3].

Majority of mucous retention cysts are acquired in nature and are postulated to develop from marked cystic dilatation due to partially obstructed duct by a salivary calculi, mucous plug, strictures, neoplasm or parasites [5]. Retention of secretions may lead to development of retention cysts. Epithelial-lined retention cysts may be distinguished from pseudocysts which are lined by granulation tissue. They represent an extravasation of mucous into the salivary parenchyma.

Mucous retention cysts of major salivary glands are common in the parotid gland and few cases are also reported in submandibular and sublingual glands which are in accordance with our case [6]. They are often located in superficial lobe of parotid gland. 
They are lined by single layer or stratified cuboidal epithelium, sometimes with mucous containing goblet cells. The cuboidal ductal epithelium may show metaplasia to squamous epithelium as in our case. They are usually unilateral, painless, compressible swelling ranging in size from 0.8 to $10 \mathrm{~cm}$. Our case presented with the lesion size of $5 \times 4 \times 3 \mathrm{~cm}$. The past literature states that children to older adults are usually affected and majority of the cases presents between 30 to 40 years of age, without any sex predilection [3].

Major parotid swellings are challenging, with the differential diagnosis ranging from benign cystic lesions to malignant salivary gland neoplasms. Many authors have also postulated that the salivary gland cyst may be an early manifestation of salivary gland tumor. Similar cases were documented in association with salivary gland tumors, out of which muco-epidermoid carcinoma is the commonest associated tumor followed by adenoid cystic carcinoma and adenocarcinoma [7].

The clinician, radiologist and pathologist all have a key role to arrive to the confirmative diagnosis. Radiology, the preliminary investigatory aid will not reveal the exact pathology since majority of salivary gland tumors (benign and malignant) present with a unilocular cystic radiographic appearance similar to mucous retention cyst [4]. FNAC may not disclose the hidden pathology, since the aspirated cystic content can be devoid of epithelial cells, when the needle does not hit the representative site[5]. Finally, the gross and the microscopic examination give a clue for definitive diagnosis.

\section{Concludsion}

Mucous retention cysts of major salivary glands are rare and are uncommonly associated with malignant tumors. The macroscopic and microscopic examination of specimen helps to evaluate the abnormal proliferation and nodular appearance from the cystic lining that rules out malignant transformation of the cyst.

\section{REFERENCES}

1. Ellis GL, Auclair PL, Gnepp DR. Surgical pathology of the salivary glands. In: LiVolsi VA, ed. Major Problems in Pathology, Philadelphia, PA: WB Saunders; 1998

2. Klijanienko J, Vielh P, Batsakis JG. (Eds.). Salivary gland tumours. 15ed. Karger Medical and Scientific Publishers; 2000

3. Antoniadis K, Karakasis D, Tzarou V, Skordalaki A. Benign cysts of the parotid gland. International journal of oral and maxillofacial surgery. 1990 Jun 1;19(3):139-40.

4. Vinayachandran D, Sankarapandian S. Salivary duct cyst: Histo-pathologic correlation. Journal of clinical imaging science. 2013;3(Suppl 1).

5. Qannam A, Bello IO, Al-Kindi M, Al-Hindi M. Unicystic mucoepidermoid carcinoma presenting as a salivary duct cyst. International journal of surgical pathology. $2013 \mathrm{Apr}$;21(2):181-5.

6. Takeda Y, Yamamoto H. Salivary duct cyst: its frequency in a certain Japanese population group (Tohoku districts), with special reference to adenomatous proliferation of the epithelial lining. Journal of oral science. 2001;43(1):9-13.

7. Seifert G. Mucoepidermoid carcinoma in a salivary duct cyst of the parotid gland: contribution to the development of tumours in salivary gland cysts. Pathology-Research and Practice. 1996 Jan 1;192(12):1211-7. 